Review

\title{
Climate Change along the Silk Road and Its Influence on Scythian Cultural Expansion and Rise of the Mongol Empire
}

\author{
Ping Che ${ }^{1}$ and Jianghu Lan ${ }^{2,3,4, *(\mathbb{D})}$ \\ 1 Department of Foreign Languages, Xianyang Normal University, Xianyang 712000, China; \\ pauline319@163.com \\ 2 State Key Laboratory of Loess and Quaternary Geology, Institute of Earth Environment, \\ Chinese Academy of Sciences, Xi'an 710061, China \\ 3 China-Pakistan Joint Research Center on Earth Sciences, Chengdu 610041, China \\ 4 Center for Excellence in Quaternary Science and Global Change, Chinese Academy of Sciences, \\ Xi'an 710061, China \\ * Correspondence: lanjh@ieecas.cn or lanjh115@163.com
}

Citation: Che, P.; Lan, J. Climate Change along the Silk Road and Its Influence on Scythian Cultural Expansion and Rise of the Mongol Empire. Sustainability 2021, 13, 2530. https://doi.org/10.3390/su13052530

Academic Editor: Leslie A. Duram

Received: 8 February 2021

Accepted: 21 February 2021

Published: 26 February 2021

Publisher's Note: MDPI stays neutral with regard to jurisdictional claims in published maps and institutional affiliations.

Copyright: (c) 2021 by the authors. Licensee MDPI, Basel, Switzerland. This article is an open access article distributed under the terms and conditions of the Creative Commons Attribution (CC BY) license (https:// creativecommons.org/licenses/by/ $4.0 /)$.

\begin{abstract}
Climate change and cultural exchange both influenced cultural development along the continental Silk Road during the late Holocene, but climate change and its influence on nomadic civilizations during that time has yet to be systematically assessed. In this study, we analyzed records of climate change along the Silk Road covering key periods in the late Holocene, based on multiproxies from various archives including lake sediments, shorelines/beach ridges, peatlands, ice cores, tree rings, aeolian sediments, moraines, and historical documents. Combined with archaeological data, we assessed the influence of climate on development and expansion of representative pastoral nomadism. Our results show that the most notable climate changes in Central Asia were characterized by decreasing temperature, expanding glaciers, increasing precipitation, and increasing humidity during transitions from the Sub-Boreal to Sub-Atlantic Period (ca. 9-8th century BC) and from the Medieval Warm Period to the Little Ice Age (ca. 13-14th century AD). The two periods coincided with Scythian Cultural expansion across the steppe landscape of Central Asia and rise of the Mongol Empire, respectively. These temporal coincidences are interpreted as causally related, where temperature fall and glacial advance may have forced the pastoral nomadism to southward migration. Coeval wetness and southward migration of steppe landscape in Central Asia were beneficial for these cultural expansions, which spanned the Eurasian arid and semi-arid zone westward. Therefore, during the historical period when productivity was underdeveloped, although expansions of pastoral nomadism were closely related to internal social structures, climate change was possibly the most critical controlling factor for sustainability development and collapse.
\end{abstract}

Keywords: Sub-Atlantic Period; Little Ice Age; lake sediment; shoreline; climate change; culture expansion

\section{Introduction}

Spanning Eurasia, the Silk Road was not only an important trade passageway linking Eastern Asia and Europe in historical times but also a channel for technical, intellectual, and cultural exchange across Asia and Europe, and a link between Eastern and Western civilizations [1]. The arid and semi-arid zone, located in the hinterland of the Eurasian continent, is a key area within the continental Silk Road Economic Belt and is one of the driest areas in the world, with a fragile ecological environment highly sensitive to climate change [2,3]. A comprehensive study into climate change during this historical period has the potential to greatly increase our understanding of key issues, such as climate change process, its driving mechanisms, and prospective variations and trends, and could provide scientific evidence regarding possible climatic risks that the national "Belt and Road Initiative" [4]. In addition, previous studies showed that extensive cultural 
exchange between Eastern and Western civilizations occurred along the ancient Silk Road in prehistoric times [5-8]. Pagel et al. [9] even suggested that thousands of European and Asian languages split from a Eurasian language 15,000 years ago. The differentiation and dissemination of languages is closely related to human activities, which are in turn influenced by climate change [10]. Hence, interpreting past climate change is important for understanding social change, cultural/civilization exchange, and language evolution in Eurasia during prehistoric and historical periods.

Instrumental data are widely used to carry out climate change research, but there are clear limitations in temporal and spatial scales, which make it impossible to fully characterize past climate in this way. For example, the longest instrumental data available spans less than 200 years, and in Central Asia (including Northwest China) the data are at most only 60-70 years in length. This severely restricts our ability to obtain a comprehensive understanding of Earth's past climate system, including on annual and decadal time scales. In addition, model simulations are not yet able to provide reliable predictive results independent of natural geological records [11,12]. Therefore, the most reliable method to assess our current and arguably future climate status is to reconstruct past climate change using high-resolution natural geological and biological records, accurate dating, and multiproxy interpretation.

This study summarizes data from various geological archives, including lake sediments, shorelines/beach ridges, peatlands, ice cores, tree rings, aeolian sediments, and moraines, in the arid and semi-arid zone of Central Asia. Combined with historical records, we assess past climate change along the Silk Road during critical periods over the past 3000 years. Finally, we combine this information with archaeological data and focus on the influence of transition-related climate change (cold-warm and dry-wet cycles), and assess the ecological environment of Central Asia as related to climate change during the early Sub-Atlantic Period (ca. 9-8th century BC) and the expansion of Scythian culture, as well as during the early Little Ice Age (LIA; ca. 13-14th century AD) and the rise and westward expansion of the Mongol Empire. The aim of this study is to understand the connections more clearly between climate and environmental change, and human activities and the vicissitude of civilization along the Silk Road in prehistoric and historical periods, which is benefit for understanding the sustainability for human being, especially under the continued global warming scenario.

\section{Study Region}

Central Asia is located in the mid-latitudes of the Northern Hemisphere, deep within the hinterland of the Eurasian continent. Its terrain is largely composed of low-elevation $(<1000-1500 \mathrm{~m})$ inland plains and high-altitude mountain systems $(>2500 \mathrm{~m})$. From west to east, they comprise the Central Asian Plain, Southern Siberian Plain, Altai MountainsTianshan Mountains-Pamir Plateau, Junggar Basin, Tarim Basin, and Mongolian Plateau (Figure 1). Blocked by high terrains, monsoon circulations are unable to penetrate into the region, and therefore precipitation largely depends on water vapor carried in by midlatitude Westerlies circulation [2,3,13-18]. The sides of high mountain ranges act as "water towers" and water conservation areas, with average annual rainfall of $>500 \mathrm{~mm}$ in windward slope. Conversely, precipitation over the plains and basins is scarce, with annual mean rainfall of $<200-300 \mathrm{~mm}$, and even less $(<50 \mathrm{~mm})$ in extremely arid water-consumption areas. Precipitation in northern semi-humid areas is greater than southern arid and semi-arid areas, which influences the natural landscapes which are, from north to south, the northern Taiga, central grassland-steppe, and southern Gobi Desert [19-21]. Human activities largely took place in the foothills of mountains in oasis zones [2], which hosted the central routes of the Silk Road between East Asia and eastern Mediterranean (trans-Eurasian exchange) [8]. Recently, Tan et al. [8] suggested that after the middle Holocene megadrought, the earliest transcontinental exchange started at the 5th millennium BP along the Eurasian steppe. 


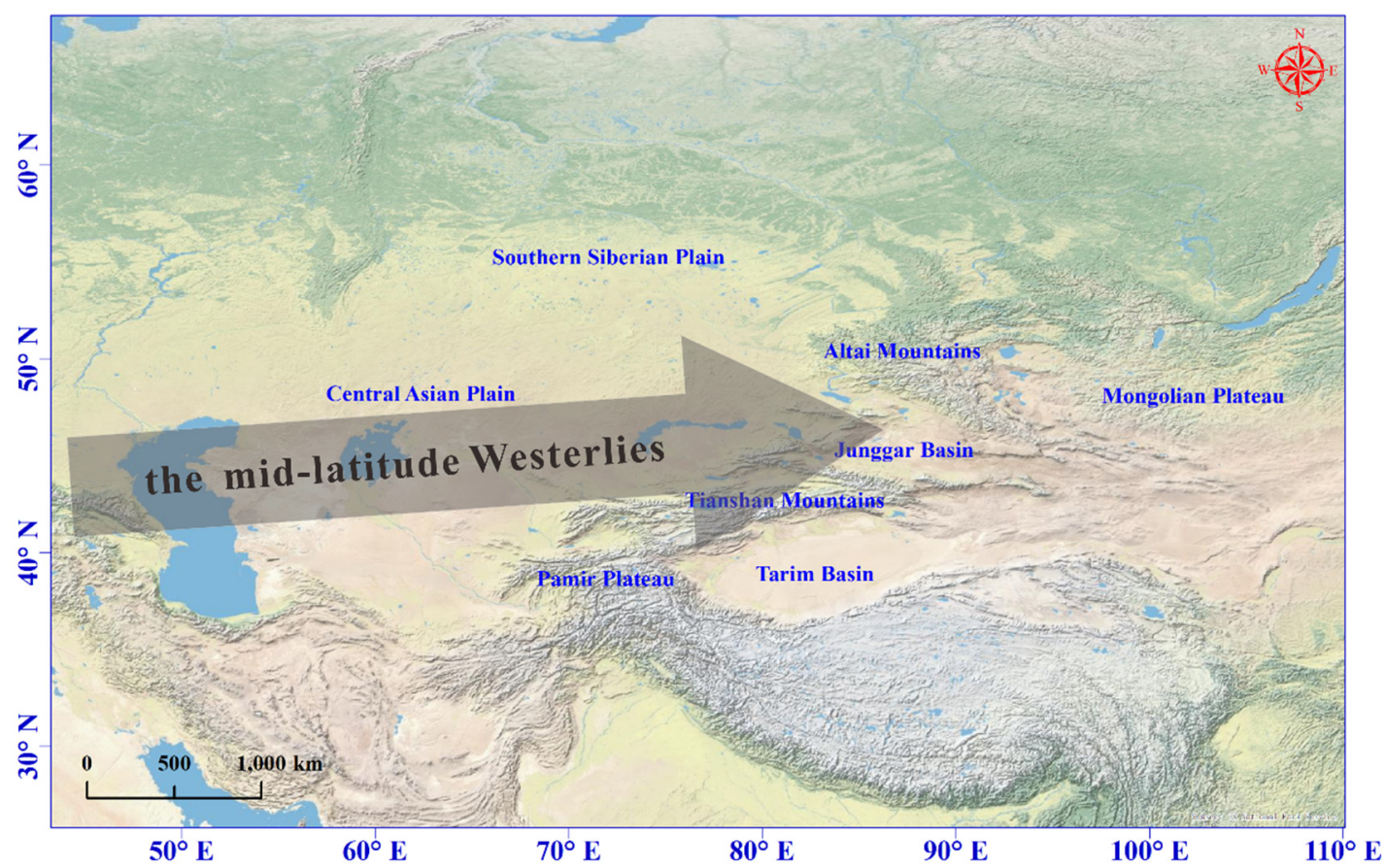

Figure 1. The spatial distribution of mainly geomorphic units in Central Asia and the mid-latitude Westerlies circulation.

\section{Materials and Methods}

Much research has been published on late Holocene climate change in Central Asia $[3,15,17,22]$. Over the past decade, with the improvement of dating methods and the comprehensive application of multiproxy indictors, the mysteries of late Holocene climate change in Central Asia have become gradually clear. In this study, we selected previously published records with the most reliable chronologies and proxy indicators from various archives, such as lake sediments, shorelines/beach ridges, peatlands, ice cores, tree rings, aeolian deposits, moraines, and historical documents, to assess the climate change over the past 3000 years. The database of the records is according to several criteria: (1) records from semi-humid, semi-arid, and arid areas in Central Asia; (2) records covering our target transition periods in the late Holocene (i.e., the transitions from the Sub-Boreal to the Sub-Atlantic Period and the Medieval Warm Period (MWP) to the LIA); (3) records with a reliable chronology (the "reservoir effect" on chronology of lake sediments was evaluated); and (4) proxies are sensitive to the changes of cold-warm and dry-wet. Based on these criteria, we selected 40 records, which include 30 lake deposits and shorelines/beach ridges, 4 peatlands, 1 ice core, 1 tree rings, 2 aeolian deposits, 2 moraines, and 1 historical document. Site distribution is shown in Figures 2 and 3, and more detailed information is listed in Table 1.

It should be note that, all ages were calibrated from original laboratory ${ }^{14} \mathrm{C}$ dates to calendar years before present (1950 AD) using the Calib Rev 7.0.2 [23,24]; and we then present them as $B C$ and $A D$. 


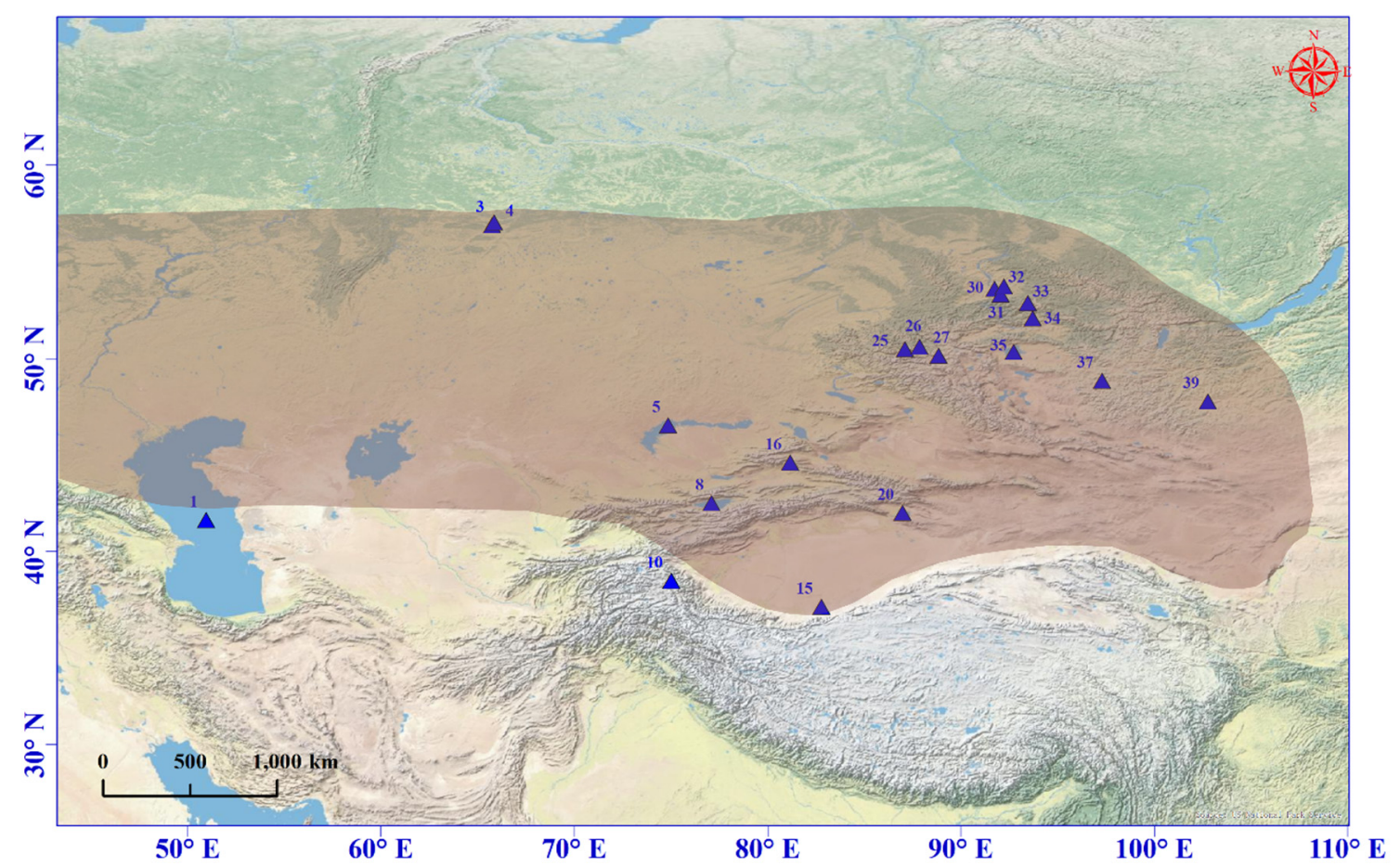

Figure 2. The distribution of climate records in Central Asia during the Scythian cultural period (ca. 9th-3rd century BC; A list of sites, including references for each record, can be found in Table 1). The brown shaded area indicates the largest areal extent influenced by Scythian culture influenced [25,26].

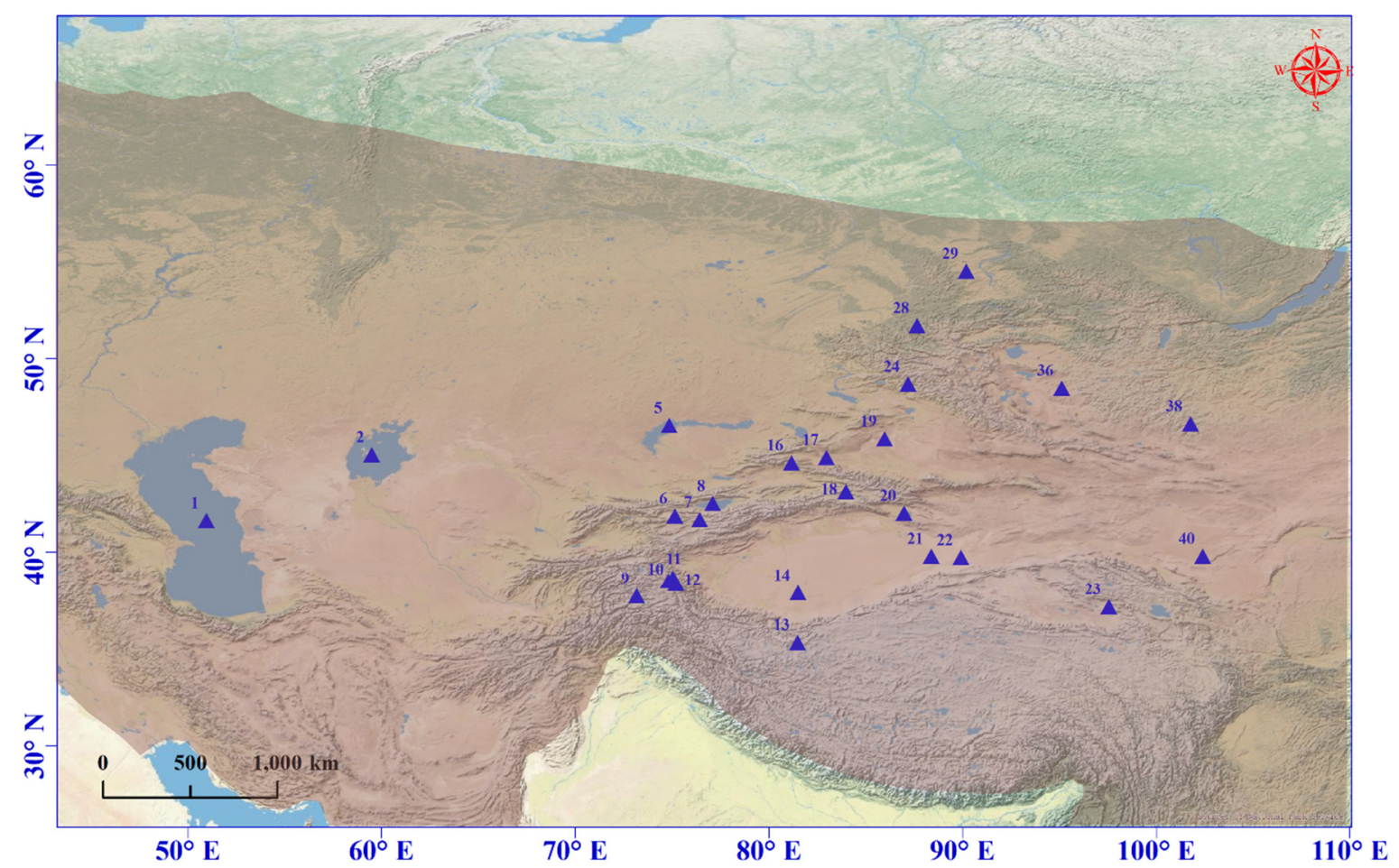

Figure 3. The distribution of climate records in Central Asia during the Mongol Empire period (ca. 13th-14th century AD; Site numbers show in Table 1). The brown shaded area shows the largest areal extent of the Mongol Empire [27]. 
Table 1. Paleoclimate archives referred to in this study. Site number as in Figures 2 and 3.

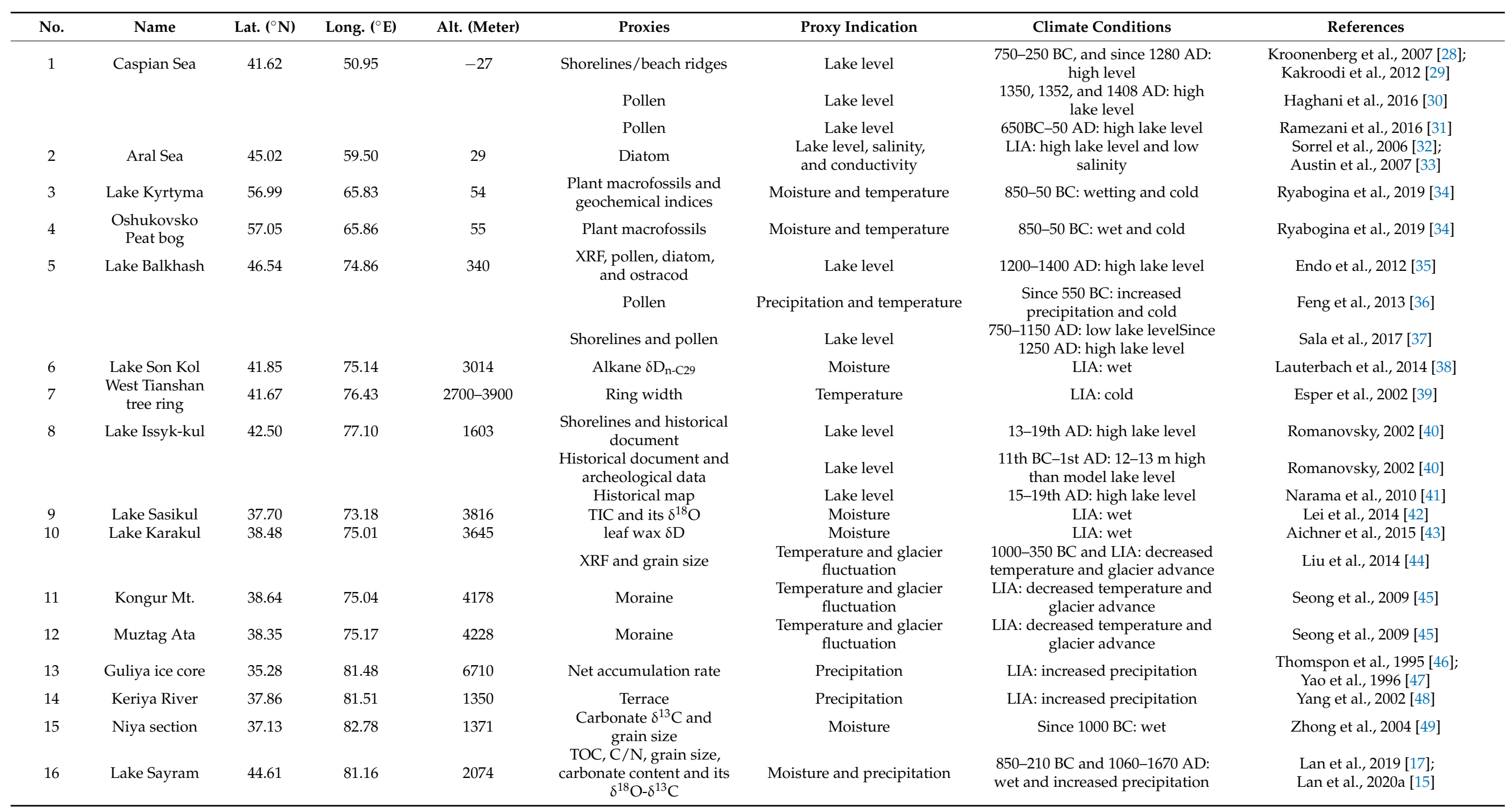


Table 1. Cont.

\begin{tabular}{|c|c|c|c|c|c|c|c|c|}
\hline No. & Name & Lat. $\left({ }^{\circ} \mathbf{N}\right)$ & Long. $\left({ }^{\circ} \mathrm{E}\right)$ & Alt. (Meter) & Proxies & Proxy Indication & Climate Conditions & References \\
\hline 17 & Lake Ebinur & 44.88 & 82.97 & 195 & $\begin{array}{l}\text { Pollen and carbonate } \\
\qquad \delta^{18} \mathrm{O}\end{array}$ & Moisture/lake level & LIA: wet and high lake level & $\begin{array}{c}\text { Ma et al., } 2011 \text { [50]; } \\
\text { Wang et al., } 2013 \text { [51] }\end{array}$ \\
\hline 18 & Lake Harnur & 43.11 & 83.97 & 2941 & Grain size & Precipitation and temperature & $\begin{array}{l}\text { 1300-1870 AD: increased } \\
\text { precipitation and cold }\end{array}$ & Lan et al., 2018 [22] \\
\hline 19 & Lake Manas & 45.83 & 85.97 & 244 & Alkenone $\% \mathrm{C}_{37: 4}$ & Salinity/lake level & $\begin{array}{l}\text { LIA: low salinity and high lake } \\
\text { level }\end{array}$ & Song et al., 2015 [52] \\
\hline 20 & Lake Bosten & 41.99 & 86.98 & 1051 & $\begin{array}{c}\text { Alkenone } \mathrm{U}^{\mathrm{K}^{\prime}}{ }_{37} \\
\text { Grain size, TOC, pollen, } \\
\text { carbonate content and its } \\
\delta^{18} \mathrm{O}-\delta^{13} \mathrm{C}\end{array}$ & Temperature & 1050-220 BC and LIA: wet & $\begin{array}{l}\text { Song et al., } 2015 \text { [52] } \\
\text { Chen et al., } 2006 \text { [53]; Zhang et al., } \\
2010 \text { [54]; Zhou et al., } 2020 \text { [55] }\end{array}$ \\
\hline 21 & $\begin{array}{l}\text { Eastern Tarim } \\
\text { Basin }\end{array}$ & 39.77 & 88.38 & 814 & Plant $\delta^{13} \mathrm{C}$ & Moisture & LIA: wet & Liu et al., 2011 [56] \\
\hline 22 & Lop Nur & 39.71 & 89.92 & 791 & Shorelines & Lake level & 1180 AD: high level & Putnam et al., 2016 [57] \\
\hline 23 & Lake Gahai & 37.13 & 97.55 & 2852 & Alkenone $\mathrm{U}^{\mathrm{K}^{\prime}}{ }_{37}$ & Temperature & LIA: cold & He et al., 2013 [58] \\
\hline 24 & Big Black peat & 48.67 & 87.18 & 2167 & Cellulose $\delta^{18} \mathrm{O}$ & Moisture & LIA: wet & Xu et al., 2019 [16] \\
\hline 25 & Lake Uzunkol & 50.48 & 87.11 & 1985 & Pollen & Temperature & 850-250 BC: cold & Blyakharchuk et al., 2004 [59] \\
\hline 26 & LakeKendegelukol & 50.49 & 87.65 & 2050 & Pollen & Moisture & 850-150 BC: wet & Blyakharchuk et al., 2004 [59] \\
\hline 27 & Kuray Basin & 50.13 & 88.85 & 2330 & Pollen & Moisture & 950-210 BC: wet & Schlütz and Lehmkuhl, 2007 [60] \\
\hline 28 & $\begin{array}{l}\text { Lake } \\
\text { Teletskoye }\end{array}$ & 51.70 & 87.65 & 430 & Pollen & Temperature & Since 1250 AD: cold & Rudaya et al., 2016 [61] \\
\hline 29 & Lake Shira & 54.51 & 90.19 & 349 & Pollen & Moisture & Since $1200 \mathrm{AD}$ : wet & Hildebrandt et al., 2015 [62] \\
\hline 31 & $\begin{array}{c}\text { Lake } \\
\text { Shushenskoe }\end{array}$ & 53.31 & 92.05 & 272 & Pollen & Moisture & 880-150 BC: wet & Dirksen et al., 2007 [64] \\
\hline 32 & $\begin{array}{l}\text { Lake Big } \\
\text { Kyzykul }\end{array}$ & 53.73 & 92.11 & 342 & Pollen & Moisture & 930 BC-400 AD: wet & Dirksen et al., 2007 [64] \\
\hline 33 & Lugovoe peat & 52.86 & 93.36 & 1299 & Pollen & Moisture & 900-400 BC: wet & Blyakharchuk et al., 2019 [65] \\
\hline 34 & Lake White & 52.07 & 93.71 & 830 & Pollen & Moisture & 850-50 BC: wet & $\begin{array}{l}\text { Dirksen and van Geel, } 2004 \text { [63]; } \\
\quad \text { van Geel et al., 2004 [25] }\end{array}$ \\
\hline 35 & Uvs Nuur & 50.32 & 92.72 & 760 & Shoreline & Lake level & $850 \mathrm{BC}$ : high lake level & Grunert et al., 2000 [66] \\
\hline 36 & Bayan Nuur & 48.46 & 95.11 & 1505 & Pollen & Moisture & 1150-1850 AD: wet & Yang et al., 2020 [67] \\
\hline 37 & Lake Telmen & 48.83 & 97.29 & 1789 & $\begin{array}{l}\text { Pollen, } \mathrm{CaCO}_{3}, \mathrm{X} \text {-ray } \\
\text { mineralogy, diatom, } \\
\text { ostracod, TOC, } \delta^{13} \mathrm{C}\end{array}$ & Moisture & Since 760 BC: wet & Peck et al., 2002 [68] \\
\hline 38 & Lake Khuisiin & 46.61 & 101.76 & 2280 & Pollen & Moisture & 1380-1830 AD: wet & Tian et al., 2013 [69] \\
\hline 39 & Ugii Nuur & 47.76 & 102.77 & 1332 & Pollen & Moisture & 850-250 BC: wet & $\begin{array}{l}\text { Wang et al., } 2009 \text { [70]; } \\
\text { Wang et al., } 2011 \text { [71] }\end{array}$ \\
\hline 40 & $\begin{array}{l}\text { Badain Jaran } \\
\text { Desert }\end{array}$ & 39.77 & 102.40 & 1398 & Chloride concentration & $\begin{array}{l}\text { Recharge rate of } \\
\text { groundwater/Moisture }\end{array}$ & LIA: wet & $\begin{array}{l}\text { Ma and Edmunds, } 2006 \text { [72]; } \\
\text { Gates et al., } 2008 \text { [73] }\end{array}$ \\
\hline
\end{tabular}




\section{Synthesis}

As shown in Table 1 and Figures 3 and 4, the Central Asia has evidently experienced a series of climate change events during the late Holocene, in which lower temperature and glacier advance are remarkably attendant with enhanced precipitation, higher lake level, and increased moisture during the early Sub-Atlantic Period (ca. 850-200 BC) and early LIA (ca. 13-14th century AD). Furthermore, based on the archaeological data and historical materials, we found that the Scythian culture and the Mongol Empire were blooming and expansion at ca. 9th-3rd century BC and 1206-1368 AD, respectively, which are both broadly contemporaneous with the cold-wet climate conditions in Central Asia. In the following section, we discuss the climate change in detail and assess its influence on Scythian cultural expansion and rise of the Mongol Empire.

\subsection{Climate Variations during Key Intervals of the Past 3000 Years}

Owing to a decrease in solar radiation, earth's climate system during the late Holocene has experienced significant long-term cooling with a series of centennial-scale climate oscillations. Among these, the most significant features are the transitions from the SubBoreal to the Sub-Atlantic Period, the Roman Warm Period to the Dark Age Cold Period (DACP), and the MWP to the LIA. Although the timings of these well-known climate transitions are possibly diachronous on a global scale [12], they are likely synchronous on a regional scale $[14,15,74]$. By analysis of multiple geological archives and historical document, this study focuses on climatic characteristics of the early Sub-Atlantic period and the early LIA.

\subsubsection{Temperature and Glacier Fluctuations}

In the early first millennium BC (ca. 1000-800 BC), the Northern Hemisphere climate became significantly colder than the Sub-Boreal to Sub-Atlantic Period (Figure 4) [25,75-77], with glacier advances [78]. During the Roman Warm Period, temperature rose again, whereby the subsequent low temperature during the DACP and the LIA were interrupted by the MWP (Figure 4) [79-83].

In Central Asia, temperature decreased, and glaciers expanded during the early Sub-Atlantic Period (Figure 4) $[34,44,63,84,85]$. For example, in the forest-steppe ecotone of northern Central Asia (southern Western Siberia), the combination of geochemical proxies and plant macrofossils of Lake Kyrtyma and Oshukovskoe peat bog recorded a significant cooling at ca. $850 \mathrm{BC}$ [34], which is consistent with reconstructed annual average temperature change in this area [84]. Pollen-based mean annual temperature from Lake Balkhash in eastern Kazakhstan suggests that temperature in the early Sub-Atlantic Period was significantly lower than the subsequent period [36]. Unfortunately, this record does not cover the entire Sub-Atlantic Period and fails to record the Sub-Boreal to SubAtlantic transition. However, pollen records from Lake Uzunkol on the Ulagan Plateau in the Altai Mountains show that the pollen abundance of thermophilic Betula decreased significantly during ca. 850-250 BC, while cryophilous Pinus increased relatively [59], indicating that the temperature dropped sharply during this period. Similarly, records from Lake Kutuzhekovo in the Minusinsk depression of southern Siberia showed that abundance of Pinus sibirica remained low during ca. 850-50 BC, indicating that forest expansion was prevented, which could be explained by the persistence of relatively cold conditions [25,63]. In addition, from the high-altitude mountains in Central Asia, such as the Pamir, Tianshan, and Altai mountains, glaciers expanded in the early Sub-Atlantic Period [44,85-88]. For example, X-ray fluorescence spectroscopy (XRF) and grain size from alpine glacial Lake Karakul, located in the Pamir Mountains, revealed that the Muztag Glacier expanded significantly during 850-250 BC (Figure 4) [44]. 


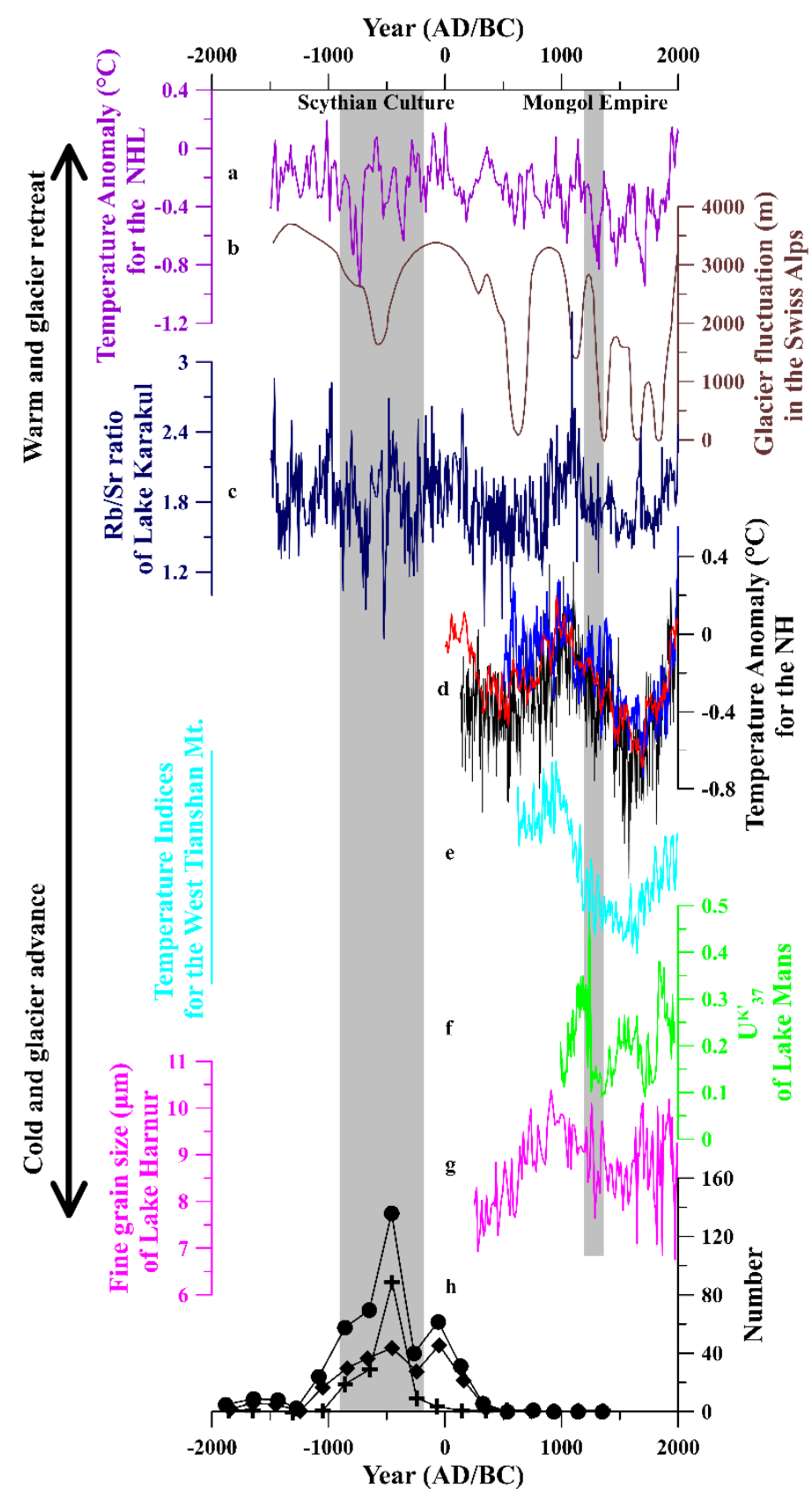

Figure 4. Temperature variations and glacier fluctuations in Northern Hemisphere (NH) and Central Asia during the late Holocene. (a) Northern high-latitude (NHL) temperature anomalies (from the base year of 1961-1990) reconstructed from argon and nitrogen isotopes from trapped air in a GISP2 ice core [76], (b) Swiss Alps Glacier fluctuations [78], (c) glacier fluctuations indicated by Rb/Sr ratio of Lake Karakul on the Pamir Plateau [44], (d) temperature anomalies for the NH (black line [79]; blue line [80]) and the extra-tropical NH (red line [81]), (e) temperature indices for the West Tianshan Mountains based on tree ring width [39], (f) temperature indices for the northwestern China by analysis of $\mathrm{U}^{\mathrm{K}^{\prime}} 37$ in Lake Manas [52], (g) temperature indices of Central Tianshan Mountains based on fine-grain size in Lake Harnur [22], and (h) number of ${ }^{14} \mathrm{C}$ dates of late Holocene archaeological sites for southern Siberia and central Asia (dot line), Tuva (cross line), and Khakassia (diamond line) [25]. The gray shadings indicate the Scythian culture blooming and expansion during the early Sub-Atlantic Period and the Mongol Empire during the early Little Ice Age (LIA).

Moreover, tree ring, ice core, lake sediment, marine sediment, speleothem, coral, glacier ice, and documentary [12,79-81,83] have clearly suggested that the Northern Hemi- 
sphere temperature dropped and glaciers advanced significantly during the LIA (Figure 4). In Central Asia, 1300 years tree ring data from the West Tianshan Mountains in western Central Asia suggest that temperatures during the LIA were significantly lower than for the MWP, and that below-average temperatures started to occur in 1140 AD [39]. This interpretation was supported by sediment-grain-size data of Lake Harnur in the Central Tianshan Mountains [22]. Sedimentary biomarkers from Lake Gahai and Lake Manas in northwest China showed that significant cooling during the LIA began at ca. 1250 $\mathrm{AD}[52,58,89]$. The temperature reconstructions from Lake Teletskoye in the northeastern Altai Mountains showed that the LIA began at ca. $1200 \mathrm{AD}$, and that temperature fell by more than $3{ }^{\circ} \mathrm{C}$ [61]. In terms of glacial activity, sedimentary $\mathrm{Rb} / \mathrm{Sr}$ ratios from Lake Karakul in the Pamirs revealed that the Muztag Glacier expanded significantly during ca. 1200-1870 AD (Figure 4) [44], which is consistent with the ${ }^{10}$ Be exposure age of moraines on Muztag Ata and Kongur Mountains [45]. Dating from ${ }^{10} \mathrm{Be},{ }^{14} \mathrm{C}$, and optically stimulated luminescence (OSL) of moraines in the Tianshan and Altai Mountains also showed that the LIA experienced significant glacial expansion in that interval $[88,90,91]$. The glacial area in the Altai Mountains during the LIA maximum was twice as large as today, and the average weighted equilibrium line altitude (ELA) fell by $\sim 89 \mathrm{~m}$ during the LIA maximum [92].

In summary, an increasing body of evidence suggests temperatures in Central Asia decreased during the early Sub-Atlantic and the LIA, associated with significant glacial advance.

\subsubsection{Hydroclimatic Variations}

Hydroclimatic variations during the late Holocene in Central Asia are better constrained than temperature and glacier fluctuations (Table 1). For example, Chen et al. [3] have first comprehensively reconstructed the moisture changes over the last millennium in arid Central Asia based on multiple proxies from 17 paleorecords, suggesting the LIA was relatively humid (Figure 5). This finding was supported by 34 geological records in this region [93]. Subsequently, by analysis of the hydroclimatic change over the last 2000 and 4000 years in Central Asia, Lan et al. $[15,17,22]$ found a series of increased precipitation and/or moisture periods during the late Holocene and suggested a prevailing warm-dry and cold-wet hydroclimatic pattern over the Westerlies-dominated Central Asia during the past two millennia (Figure 5).

Geological evidences from the Caspian Sea have shown that sea level was about 3-4.5 m higher than modern sea level during 750-250 BC and since $1280 \mathrm{AD}$, indicating that the Caspian Sea had higher sea level during the early Sub-Atlantic and LIA periods (Figure 5) $[28,29,94,95]$. Pollen data from the Mazgah and Langarud wetlands in the southern coast of the Caspian Sea showed that tree growth was hampered during the early Sub-Atlantic Period and the LIA due to brackish water invasion during sea-level rise [30,31]. Furthermore, sedimentary diatoms from the Aral Sea indicate that salinity and palaeoconductivity decreased and sea level rose during 1350-1780 AD (Figure 5) [32,33]. Lake Kyrtyma and Oshukovskoe peat bog plant macrofossils from northern Central Asia show that Carex aquatilis reached its maximum abundance at 850-50 BC, suggesting summer precipitation and groundwater levels increased significantly during that interval, marking it the wettest stage of the late Holocene [34]. Pollen data from Lake Balkhash showed that the Artemisia/Chenopodium ratio was highest in the early Sub-Atlantic Period, indicating a humid climatic environment, which is further evidenced by a quantitative reconstruction of precipitation from pollen [36]. By analysis of sedimentary multiproxies, such as XRF, pollen, diatom, and ostracod, Endo et al. [35] proposed that Lake Balkhash had low water levels during the MWP, which rose significantly at 1200 AD. Lake Balkhash subsequently experienced a short-term water level fall in the 16th century, and then a rise again in the 17-19th century [35,37] that was also recorded in historical documents [41].

Evidence from the arid region of northwest China also indicates a clear wetness during the early Sub-Atlantic Period and LIA (Figure 5). For example, $\delta^{13} \mathrm{C}$ of carbonate and grain size in Niya Section [49], and $\delta^{18} \mathrm{O}$ and $\delta^{13} \mathrm{C}$ of carbonate, carbonate mineralogy, and grain size in Lake Bosten [54] from the Tarim Basin indicate moist climate condition and low 
salinity since ca. $1000 \mathrm{BC}$, indicating that the climate and environment had ameliorated in the early Sub-Atlantic Period (Figure 5). Furthermore, a large body of evidence has record an increase in precipitation and humidity as well as lake level during the LIA (Figure 5), such as terraces of Keriya River [48], pollen, carbonate content, and other proxy indicators from Lake Bosten [53-55], plant remains $\delta^{13} \mathrm{C}$ of aeolian sand sediment section in eastern Tarim Basin [56], shorelines of Lop Nor [57], pollen and $\delta^{13} \mathrm{C}$ and $\delta^{18} \mathrm{O}$ of bulk carbonate, and $\delta^{13} \mathrm{C}$ of organic matter from Lake Ebinur [50,51], biomarkers from Lake Manas [52], and the exchange rate of groundwater in the Badain Jaran Desert [72,73]. Especially, Putnam et al. [57] systematically studied geological evidence from Lop Nur, and proposed that the humid LIA inferred from high lake level start as early as at $1180 \mathrm{AD}$.

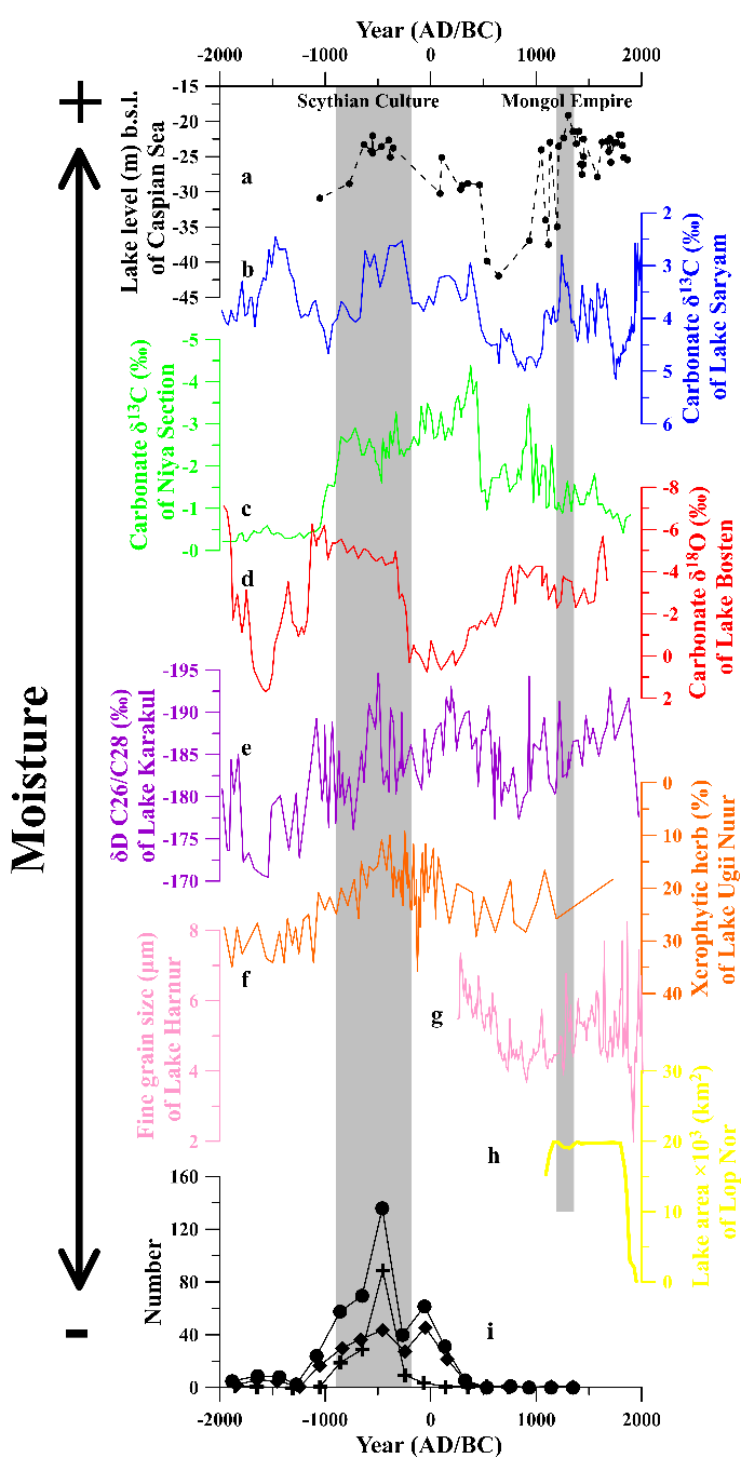

Figure 5. Hydroclimatic variation in Central Asia during the late Holocene. (a) Absolute lake level below global sea level (b.s.1.) of Caspian Sea [28-30,94,95], (b) carbonate $\delta^{13} \mathrm{C}$ of Lake Sayram in Tianshan Mountains [15], (c) carbonate $\delta^{13} \mathrm{C}$ of Niya Section in the southern Tarim Basin [49], (d) Carbonate $\delta^{18} \mathrm{O}$ of Lake Bosten [54], (e) biomarker $\delta \mathrm{D}$ of Lake Karakul from Pamir Plateau [43], (f) Xerophytic herb content of Lake Ugii Nuur in Mongolia Plateau [70,71], (g) fine-grain size of Lake Harnur in Tianshan Mountains [22], (h) lake area of Lop Nor [57], and (i) number of ${ }^{14} \mathrm{C}$ dates of late Holocene archaeological sites for southern Siberia and central Asia (dot line), Tuva (cross line), and Khakassia (diamond line) [25]. The gray shadings indicate the Scythian culture blooming and expansion during the early Sub-Atlantic Period and the Mongol Empire during the early LIA. 
Evidence from the high mountains of Central Asia further shows that the climate had become significantly wetter during the early Sub-Atlantic Period and LIA. The biomarker evidence from Lake Karakul in the Pamir Plateau indicates a humid climate condition during the early Sub-Atlantic Period and LIA (Figure 5) [43], which is supported by the biomarker and geochemical data of Lake Sasikul [42] in the Pamir Plateau especially during the LIA. Hydrogen isotopes of $C_{29} n$-alkanes $\left(\delta D_{n-C 29}\right)$, a proxy for summer precipitation in Lake Son Kol in western Tianshan Mountains, are significantly negative since 1100 AD, indicating increased summer precipitation during the LIA [38]. Shorelines/beach ridges, historical documents, and archaeological data from Lake Issyk-Kul, also located in western Tianshan Mountains, demonstrated that the lake level between the 11th century BC and the 1st century AD was 12-13 m higher than the modern level discharged into Boom canyon, and it rose again and outflowed in the 13-19th century [40,41]. Multiproxies from Lake Sayram in the Central Tianshan Mountains not only record an increase in precipitation and effective humidity from 850 to 210 BC but also significant wetness at 1060-1670 AD (the early LIA) $[15,17,96]$, which is supported by grain-size data from Lake Harnur in the Central Tianshan Mountains (Figure 5) [22].

Pollen data of lake and peat records in the Altai and Sayan Mountains show the characteristic of increased humidity and rising lake levels in the early Sub-Atlantic Period and LIA (Table 1) $[16,25,59,60,62-67]$. Pollen data from Lake Telmen [68] and Lake Ugii Nuur $[70,71]$ on the Mongolian Plateau indicate the humidity increased in the early SubAtlantic Period (Figure 5). In addition, pollen from Lake Khuisiin on the Mongolian Plateau [69] and the net accumulation of the Guliya ice core in the northern Tibetan Plateau $[46,47]$ show effective humidity and precipitation increased significantly during the LIA.

In summary, evidence from various paleorecords including lake deposits, shorelines / beach ridges, peat, ice cores, tree rings, aeolian deposits, moraines, and historical documents in Central Asia indicate that the climate conditions during the early Sub-Atlantic Period (ca. 850-200 BC) and LIA (ca. 1250-1850 AD) were characterized by decreasing temperature and advancing glaciers as well as significant increases in precipitation and humidity.

\subsection{Scythian Culture Blooming and Expansion}

The Scythian culture, known for its horses' bridles, weapons, and art types (animal style), was an active nomadic culture that occupied the Eurasian steppe and forest-steppe zones during the first millennium BC, ranging from northern China in the east to the Danube River in the west [25]. Most archaeological sites are located within the range of $42-55^{\circ} \mathrm{N}$ and $30-100^{\circ} \mathrm{E}$ (Figure 2) [25,26]. According to archaeological discoveries such as the Arzhan mound of the Russian Tuva Republic, the Zargalant mound in central-western Mongolia, the Besshatyr mound in Kazakhstan, the Chertomlyk mound on the north bank of the Black Sea, and the ancient mounds on the western bank of the Dnieper, the development of Scythian culture is usually subdivided into three phases: the 9-7th century BC pre-Scythian and initial Scythian phases, the 7-6th century BC early Scythian phase, and the 5th-3rd century BC classic Scythian phase [25].

After the middle of the 9th century BC, the population density and cultural development in the Tuva Republic entered a new peak, which had a fundamental influence on the cultural development of the entire Eurasian steppe zone. The early Scythian monument site, the Arzhan-1 tomb, is located in the area of Tuva Republic. ${ }^{14} \mathrm{C}$ and dendrochronology suggest the ages of archaeological sites have been dated to the period between the late 9 th and early 8 th century BC $[25,65]$. The culture then expanded to the south and entered the Sayan-Altai-Tianshan Mountains region. Finally, it expanded westward, spanning the entire Central Asia and reaching the northern bank of the Black Sea and the western bank of the Dnieper (the oldest Scythian culture in Europe is the 8th century BC) [25]. From the perspective of migration direction and invasion waves, it is apparent that the nomadic culture in the Eurasian steppe zone predominantly migrated and invaded from north to south and from east to west [26]. Based on the St. Petersburg archaeological ${ }^{14} \mathrm{C}$ database, 
van Geel et al. [25] summarized and analyzed the frequency distribution of archaeological sites in southern Siberia and Central Asia during the Holocene. Results showed that the number of archaeological sites began to increase at ca. $720 \mathrm{BC}$ (ca. $3000{ }^{14} \mathrm{C}$ yr BP) (Figures 4 and 5), indicating that the acceleration of cultural development in this region took place shortly after this time [25].

As discussed above, blooming and expansion of Scythian culture (ca. 9th-3rd centuries BC) coincided with the transition from the Sub-Boreal to Sub-Atlantic Period, when the climate in Central Asia has experienced decreasing temperature and glacial advance. The colder climate led to significant changes in nomadic culture and social structure, directly driving migration and expansion of Scythian culture to the south [60]. Simultaneously, a more humid climate with increased precipitation proved conducive to the expansion of nomadic culture. Central Asia is one of the driest regions in the world, and the Gobi Desert blocked nomadic migration. However, after the transition from the Sub-Boreal to Sub-Atlantic Period, the arid Central Asia turned "green" as grasslands moved south, transforming the desert landscape into higher plant-biomass production and thus higher-carrying-capacity grassland landscape [25]. This provided a food source for horses, allowing Scythian culture to migrate westward across the arid-semi-arid Central Asia and finally reach the Danube River in southeastern Europe.

In contrast to these changes, palynological evidence from the Beloe Ozero-3 tomb (Tuva area) during late Scythian culture showed that drying climate caused gradual decline of Scythian culture [65]. Precipitation and humidity proxy records from the Altai and Tianshan Mountains in Central Asia also show a gradual shift toward aridification at ca. 250-200 BC $[15,17,59,60,64]$. Therefore, in the last stage of the classic Scythian phase, the Scythian culture gradually decline and finally withdraw from the historic stage, resulting from the end of the humid early Sub-Atlantic Period.

\subsection{The Rise of the Mongol Empire and Its Expansion}

The Mongol Empire (1206-1368 AD) is a general term for the Mongol regime in the 13-14th century AD. It was a vast empire established by nomad across Asia and Europe, with a national territory spanning from the Pacific Ocean in the east to the Danube River and the shores of the Persian Gulf in the west, and from the South China Sea and the Indian Ocean in the south to North Asia in the north (Figure 3). In 1206 AD, Temujin, called Genghis Khan, established the Mongol Empire on the banks of the Onon River. The Mongol Empire continued to expand abroad, against the Tangut kingdom of Hsi Hsia (Xi Xia), the Liao Kingdom, the Tungusic Jin Dynasty and the Khwarezm (Khiva), and then marched through Kazakhstan/Uzbekistan to attack Eastern Europe around the Volga River. In $1241 \mathrm{AD}$, the victories approached the hinterland of Eastern Europe and conquered Poland and Hungary.

During the Mongol Empire, horse was the primary means of transportation for military conquests. According to Rossabi [97], Mongol Empire cavalry soldiers usually took three or more remounts on campaign, so the number of horses was at least three times that of the cavalry, putting enormous pressure on foraging as an energy source. During the Mongol Empire's long-ranging military campaigns, horse fodder could not be brought solely from the Mongolian steppe, but instead needed to be foraged locally. The expansion period of the Mongol Empire coincided with wetness in early LIA over the arid Central Asia $[15,17,57,96]$, while the monsoon region in northern China experienced significant aridification [14,98]. It is reasonable to assume that, owing to the southward migration of the Eurasia steppe during this period, the greening of mid-latitude Asian deserts facilitated the Mongolian cavalry crossing Central Asia toward Eastern Europe. On the other hand, with the beginning of the LIA, temperatures in Central Asia decreased, glaciers and snow cover expanded, and winters became more severe and protracted, which forced Mongolian nomad southward migration to the relatively warmer regions. Furthermore, due to the "greening" of Central Asia, oasis agriculture may have been transformed into pastoralism. At the same time, the agricultural empire in northern China experienced a rapid decline 
in the East Asian summer monsoon, causing severe droughts, famines, peasant uprisings, and a series of other societal problems $[14,98]$. Therefore, the southward migration and expansion of grassland landscapes contributed to the transformation of the agricultural civilization to the pastoral nomadism in Central Asia, ultimately strengthening their economic and cultural ties to the Mongols [57].

\section{Conclusions}

We analyzed climate change along the Silk Road during the late Holocene based on 40 records from multiple archives, such as lake sediments, shoreline/beach ridges, peatlands, ice cores, tree rings, aeolian deposits, moraines, and historical documents. We combined this information with archaeological data to establish the climatic influence on the development and expansion of the representative pastoral nomadism, such as the expansion of Scythian culture and rise of the Mongol Empire. The main point of our review paper thus is closely linked to both regional and global concerns of sustainability.

Our results show that the Silk Road experienced a succession of cold-warm and drywet cycles during the late Holocene. Among these, the most notable changes were characterized by decreasing temperature, expanding glacier, increasing precipitation, and increasing humidity in Central Asia, occurring over the transition from the Sub-Boreal to Sub-Atlantic Period (ca. 9-8th century BC) and from the MWP to LIA (ca. 13-14th century $\mathrm{AD}$ ). The temperature declines and glacial advances forced pastoral nomadism southward migration. Meanwhile, the wetness and southward migration of grassland landscape in Central Asia were beneficial for the expansion of Scythian culture and the Mongol Empire, which crossed the entire arid and semi-arid Eurasia. Therefore, climate change is possibly the most key factor for the development and expansion of pastoral nomadism in prehistoric and historical periods.

Author Contributions: P.C. analyzed the data and wrote the paper; J.L. conceived and designed the research and edited the paper; P.C. and J.L. reviewed and edited the paper. All authors have read and agreed to the published version of the manuscript.

Funding: This research was funded by the Strategic Priority Research Program of Chinese Academy of Sciences, grant number XDB40010300; the Natural Science Foundation of China, grant number, 41991253, U20A2078; the National Social Science Foundation of China, grant number, 18ZDA172; and the Youth Innovation Promotion Association of the Chinese Academy of Sciences.

Acknowledgments: This work is a part of the "Belt \& Road" Project of Institute of Earth Environment, Chinese Academy of Sciences.

Conflicts of Interest: The authors declare no conflict of interest.

\section{References}

1. Chen, F.H.; An, C.B.; Dong, G.H.; Zhang, D.J. The Silk Road and the Pan-Third Pole area, human activities, environmental changes and the rise and fall of the Silk Road civilization. Proc. Chin. Acad. Sci. 2017, 32, 967-975.

2. Chen, X. Physical Geography of Arid Land in China; Science Press: Beijing, China, 2010.

3. Chen, F.H.; Chen, J.H.; Holmes, J.; Boomer, I.; Austin, P.; Gates, J.B.; Wang, N.L.; Brooks, S.J.; Zhang, J.W. Moisture changes over the last millennium in arid central Asia: A review, synthesis and comparison with monsoon region. Quat. Sci. Rev. 2010, 29, 1055-1068. [CrossRef]

4. Ascensão, F.; Fahrig, L.; Clevenger, A.; Corlett, R.; Jaeger, J.; Laurance, W.; Pereira, H. Environmental challenges for the Belt and Road Initiative. Nat. Sustain. 2018, 1, 206-209. [CrossRef]

5. An, C.B.; Zhang, M.; Wang, W.; Liu, Y.; Duan, F.T.; Dong, W.M. The characterisisc of geographical environment and the F ormation of the Pattern of agriculture and animal husbandry in Xinjiang. Sci. China Earth Sci. 2020, 50, 295-304.

6. Zhou, X.; Yu, J.; Spengler, R.N.; Shen, H.; Zhao, K.; Ge, J.; Bao, Y.; Liu, J.; Yang, Q.; Chen, G.; et al. 5,200-year-old cereal grains from the eastern Altai Mountains redate the trans-Eurasian crop exchange. Nat. Plants 2020, 6, 78-87. [CrossRef]

7. Spengler, R. Fruit from the Sands: The Silk Road Origins of the Foods We Eat; University of California Press: Berkeley, CA, USA, 2019.

8. Tan, L.C.; Dong, G.H.; An, Z.S.; Edwards, R.L.; Li, H.M.; Li, D.; Spengler, R.; Cai, Y.J.; Cheng, H.; Lan, J.H.; et al. Megadrought and cultural exchange along the proto-silk road. Sci. Bull. 2021, 66, 603-611. [CrossRef]

9. Pagel, M.; Atkinson, Q.D.; SCalude, A.; Meade, A. Ultraconserved words point to deep language ancestry across Eurasia. Proc. Natl. Acad. Sci. USA 2013, 110, 8471-8476. [CrossRef] 
10. Zhang, M.; Yan, S.; Pan, W.; Jin, L. Phylogenetic evidence for Sino-Tibetan origin in northern China in the Late Neolithic. Nature 2019, 569, 112-115. [CrossRef] [PubMed]

11. Lioubimtseva, E. Climate change in arid environments: Revisiting the past to understand the future. Prog. Phys. Geogr. 2004, 28, 502-530. [CrossRef]

12. Neukom, R.; Steiger, N.; Gomez-Navarro, J.J.; Wang, J.H.; Werner, J.P. No evidence for globally coherent warm and cold periods over the preindustrial Common Era. Nature 2019, 571, 550-554. [CrossRef] [PubMed]

13. Aizen, E.M.; Aizen, V.B.; Melack, J.M.; Nakamura, T.; Ohta, T. Precipitation and atmospheric circulation patterns at mid-latitudes of Asia. Int. J. Climatol. 2001, 21, 535-556. [CrossRef]

14. Lan, J.H.; Xu, H.; Lang, Y.C.; Yu, K.K.; Zhou, P.; Kang, S.G.; Wang, X.L.; Wang, T.L.; Cheng, P.; Yan, D.N.; et al. Dramatic weakening of the East Asian summer monsoon in northern China during the transition from the Medieval Warm Period to the Little Ice Age. Geology 2020, 48, 307-312. [CrossRef]

15. Lan, J.H.; Zhang, J.; Cheng, P.; Ma, X.L.; Ai, L.; Chawchai, S.; Zhou, K.E.; Wang, T.L.; Yu, K.K.; Sheng, E.G.; et al. Late Holocene hydroclimatic variation in central Asia and its response to mid-latitude Westerlies and solar irradiance. Quat. Sci. Rev. 2020, 238, 106330. [CrossRef]

16. Xu, H.; Zhou, K.E.; Lan, J.H.; Zhang, G.L.; Zhou, X.Y. Arid Central Asia saw mid-Holocene drought. Geology 2019, 47, 255-258. [CrossRef]

17. Lan, J.H.; Xu, H.; Yu, K.K.; Sheng, E.G.; Zhou, K.E.; Wang, T.L.; Ye, Y.D.; Yan, D.N.; Wu, H.X.; Cheng, P.; et al. Late Holocene hydroclimatic variations and possible forcing mechanisms over the eastern Central Asia. Sci. China Earth Sci. 2019, 62, 1288-1301. [CrossRef]

18. Lan, J.H.; Wang, T.L.; Dong, J.B.; Kang, S.G.; Cheng, P.; Zhou, K.E.; Liu, X.X.; Wang, Y.Q.; Ma, L. The influence of ice sheet and solar insolation on Holocene moisture evolution in northern Central Asia. Earth Sci. Rev. 2021. Under Review.

19. Zakh, V.A.; Ryabogina, N.E.; Chlachula, J. Climate and environmental dynamics of the mid- to late Holocene settlement in the Tobol-Ishim forest-steppe region, West Siberia. Quat. Int. 2010, 220, 95-101. [CrossRef]

20. Zhilich, S.; Rudaya, N.; Krivonogov, S.; Nazarova, L.; Pozdnyakov, D. Environmental dynamics of the Baraba forest-steppe (Siberia) over the last 8000 years and their impact on the types of economic life of the population. Quat. Sci. Rev. 2017, 163, 152-161. [CrossRef]

21. Zhang, D.; Chen, X.; Li, Y.; Wang, W.; Sun, A.; Yang, Y.; Ran, M.; Feng, Z. Response of vegetation to Holocene evolution of westerlies in the Asian Central Arid Zone. Quat. Sci. Rev. 2020, 229, 106138. [CrossRef]

22. Lan, J.H.; Xu, H.; Sheng, E.G.; Yu, K.K.; Wu, H.X.; Zhou, K.E.; Yan, D.N.; Ye, Y.D.; Wang, T.L. Climate changes reconstructed from a glacial lake in High Central Asia over the past two millennia. Quat. Int. 2018, 487, 43-53. [CrossRef]

23. Stuiver, M.; Reimer, P.J. Extend ${ }^{14} \mathrm{C}$ data base and revised calib $3.0^{14} \mathrm{C}$ age calibration program. Radiocarbon 1993, 35, 215-230. [CrossRef]

24. Reimer, P.J.; Bard, E.; Bayliss, A.; Beck, J.W.; Blackwell, P.G.; Bronk Ramsey, C.; Buck, C.E.; Cheng, H.; Edwards, R.L.; Friedrich, M.; et al. IntCal13 and Marine13 radiocarbon age calibration curves 0-50,000 years cal BP. Radiocarbon 2013, 55, 1869-1887. [CrossRef]

25. Van Geel, B.; Bokovenko, N.A.; Burova, N.D.; Chugunov, K.V.; Dergachev, V.A.; Dirksen, V.G.; Kulkova, M.; Nagler, A.; Parzinger, H.; van der Plicht, J.; et al. Climate change and the expansion of the Scythian culture after 850 BC: A hypothesis. J. Archaeol. Sci. 2004, 31, 1735-1742. [CrossRef]

26. Hayashi, T. Scythians and Xiongnu Nomadic Civilization; Xinbei Eight Banners Cult./Hik. Cult. Enterp. Co. LTD.: Taipei, Taiwan, 2019.

27. Sugiyama, M. The Long Legacy of the Mongol Empire; Xinbei Eight Banners Cult./Hik. Cult. Enterp. Co. LTD.: Taipei, Taiwan, 2019.

28. Kroonenberg, S.B.; Abdurakhmanov, G.M.; Badyukova, E.N.; Van der Borg, K.; Kalashnikov, A.; Kasirnov, N.S.; Rychagov, G.I.; Svitoch, A.A.; Vonhof, H.B.; Wesselingh, F.P. Solar-forced 2600 BP and little ice age highstands of the Caspian sea. Quat. Int. 2007, 173, 137-143. [CrossRef]

29. Kakroodi, A.A.; Kroonenberg, S.B.; Hoogendoorn, R.M.; Mohammd Khani, H.; Yamani, M.; Ghassemi, M.R.; Lahijani, H.A.K. Rapid Holocene sea-level changes along the Iranian Caspian coast. Quat. Int. 2012, 263, 93-103. [CrossRef]

30. Haghani, S.; Leroy, S.A.G.; Khdir, S.; Kabiri, K.; Beni, A.N.; Lahijani, H.A.K. An early “Little Ice Age” brackish water invasion along the south coast of the Caspian Sea (sediment of Langarud wetland) and its wider impacts on environment and people. Holocene 2016, 26, 3-16. [CrossRef]

31. Ramezani, E.; Mrotzek, A.; Mohadjer, M.R.M.; Kakroodi, A.A.; Kroonenberg, S.B.; Joosten, H. Between the mountains and the sea: Late Holocene Caspian Sea level fluctuations and vegetation history of the lowland forests of northern Iran. Quat. Int. 2016, 408, 52-64. [CrossRef]

32. Sorrel, P.; Popescu, S.M.; Head, M.J.; Suc, J.P.; Klotz, S.; Oberhansli, H. Hydrographic development of the Aral Sea during the last 2000 years based on a quantitative analysis of dinoflagellate cysts. Palaeogeogr. Palaeoclimatol. Palaeoecol. 2006, 234, 304-327. [CrossRef]

33. Austin, P.; Mackay, A.; Palagushkina, O.; Leng, M. A high-resolution diatom-inferred palaeoconductivity and lake level record of the Aral Sea for the last 1600 yr. Quat. Res. 2007, 67, 383-393. [CrossRef]

34. Ryabogina, N.E.; Afonin, A.S.; Ivanov, S.N.; Li, H.-C.; Kalinin, P.A.; Udaltsov, S.N.; Nikolaenko, S.A. Holocene paleoenvironmental changes reflected in peat and lake sediment records of Western Siberia: Geochemical and plant macrofossil proxies. Quat. Int. 2019, 528, 73-87. [CrossRef] 
35. Endo, K.; Sugai, T.; Haraguclli, T.; Clliba, T.; Kondo, R.; Nakao, Y.; Nakayama, Y.; Suzuki, S.; SIlimizu, I.; Sato, A.; et al. Lake level changes and environmental evolution during the last 8000 years based on Balkhash lake cores in Kazakhstan, Central Eurasia. In Toward A Sustainable Society in Central Asia: An Historical Perspective on the Future; Kubota, J., Watanabe, M., Eds.; Ili Project: Kyoto, Japan, 2012; pp. 2007-2012.

36. Feng, Z.D.; Wu, H.N.; Zhang, C.J.; Ran, M.; Sun, A.Z. Bioclimatic change of the past 2500 years within the Balkhash Basin, eastern Kazakhstan, Central Asia. Quat. Int. 2013, 311, 63-70. [CrossRef]

37. Sala, R.; Deom, J.M.; Nigmatova, S.; Endo, K.; Kubota, J. Soviet, recent and planned studies of the behavior of the Balkhash Lake. Natl. Acad. Sci. Kazakhstan Ser. Geol. Techn. Sci. 2017, 2, 76-86.

38. Lauterbach, S.; Witt, R.; Plessen, B.; Dulski, P.; Prasad, S.; Mingram, J.; Gleixner, G.; Hettler-Riedel, S.; Stebich, M.; Schnetger, B.; et al. Climatic imprint of the mid-latitude Westerlies in the Central Tian Shan of Kyrgyzstan and teleconnections to North Atlantic climate variability during the last 6000 years. Holocene 2014, 24, 970-984. [CrossRef]

39. Esper, J.; Schweingruber, F.H.; Winiger, M. 1300 years of climatic history for Western Central Asia inferred from tree-rings. Holocene 2002, 12, 267-277. [CrossRef]

40. Romanovsky, V.V. Water level variations and water balance of Lake Issyk-Kul. In Lake Issyk-Kul: Its Natural Environment; Klerkx, J., Imanackunov, B., Eds.; Springer: Dordrecht, The Netherlands, 2002; pp. 45-57.

41. Narama, C.; Kicengge; Kubota, J.; Shatravin, V.I.; Duishonakunov, M.; Moholdt, G.; Abdrakhmatov, K. The lake-level changes in Central Asia during the last 1000 years based on historical map. In Proceedings of International Workshop on "Reconceptualizing Cultural and Environmental Change in Central Asia: An. Historical Perspective on the Future"; Research Institute for Humanity and Nature: Kyoto, Japan, 2010; pp. 11-27.

42. Lei, Y.B.; Tian, L.D.; Bird, B.W.; Hou, J.Z.; Ding, L.; Oimahmadov, I.; Gadoev, M. A 2540-year record of moisture variations derived from lacustrine sediment (Sasikul Lake) on the Pamir Plateau. Holocene 2014, 24, 761-770. [CrossRef]

43. Aichner, B.; Feakins, S.J.; Lee, J.E.; Herzschuh, U.; Liu, X. High-resolution leaf wax carbon and hydrogen isotopic record of the late Holocene paleoclimate in arid Central Asia. Clim. Past 2015, 11, 619-633. [CrossRef]

44. Liu, X.; Herzschuh, U.; Wang, Y.; Kuhn, G.; Yu, Z. Glacier fluctuations of Muztagh Ata and temperature changes during the late Holocene in westernmost Tibetan Plateau, based on glaciolacustrine sediment records. Geophys. Res. Lett. 2014, 41, 6265-6273. [CrossRef]

45. Seong, Y.B.; Owen, L.A.; Yi, C.L.; Finkel, R.C. Quaternary glaciation of Muztag Ata and Kongur Shan: Evidence for glacier response to rapid climate changes throughout the Late Glacial and Holocene in westernmost Tibet. Geol. Soc. Am. Bull. 2009, 121, 348-365. [CrossRef]

46. Thompson, L.G.; Mosleythompson, E.; Davis, M.E.; Lin, P.N.; Dai, J.; Bolzan, J.F.; Yao, T. A 1000 year climate ice-core record from the Guliya ice cap, China: Its relationship to global climate variability. Ann. Glaciol. 1995, 21, 175-181. [CrossRef]

47. Yao, T.D.; Qin, D.H.; Tian, L.D.; Jiao, K.Q.; Yang, Z.H.; Thompson, L.G. Changes in temperature and precipitation in the Qinghai-Tibet Plateau over the past two thousand years: Guliya Ice Core Record. Sci. China Earth Sci. 1996, 26, 348-353.

48. Yang, X.P.; Zhu, Z.D.; Jaekel, D.; Owen, L.A.; Han, J.M. Late Quaternary palaeoenvironment change and landscape evolution along the Keriya River, Xinjiang, China: The relationship between high mountain glaciation and landscape evolution in foreland desert regions. Quat. Int. 2002, 97, 155-166. [CrossRef]

49. Zhong, W.; Tashpolat, T.; Wang, L.; Li, C. Process and characteristics of historical climate and environment changes in southern margin of Tarim Basin. J. Desert Res. 2004, 24, 261-267.

50. Ma, L.; Wu, J.; Yu, H.; Haiao, Z.; Abuduwaili, J. The Medieval Warm Period and the Little Ice Age from a sediment record of Lake Ebinur, northwest China. Boreas 2011, 40, 518-524.

51. Wang, W.; Feng, Z.D.; Ran, M.; Zhang, C.J. Holocene climate and vegetation changes inferred from pollen records of Lake Aibi, northern Xinjiang, China: A potential contribution to understanding of Holocene climate pattern in East-central Asia. Quat. Int. 2013, 311, 54-62. [CrossRef]

52. Song, M.; Zhou, A.F.; Zhang, X.N.; Zhao, C.; He, Y.X.; Yang, W.Q.; Liu, W.G.; Li, S.H.; Liu, Z.H. Solar imprints on Asian inland moisture fluctuations over the last millennium. Holocene 2015, 25, 1935-1943. [CrossRef]

53. Chen, F.; Huang, X.; Zhang, J.; Holmes, J.A.; Chen, J. Humid Little Ice Age in arid central Asia documented by Bosten Lake, Xinjiang, China. Sci. China Earth Sci. 2006, 49, 1280-1290. [CrossRef]

54. Zhang, C.; Feng, Z.; Yang, Q.; Gou, X.; Sun, F. Holocene environmental variations recorded by organic-related and carbonaterelated proxies of the lacustrine sediments from Bosten Lake, northwestern China. Holocene 2010, 20, 363-373. [CrossRef]

55. Zhou, K.E.; Xu, H.; Lan, J.H.; Yan, D.N.; Sheng, E.G.; Yu, K.K.; Song, Y.P.; Zhang, J.; Fu, P.Q.; Xu, S. Variable late Holocene ${ }^{14}$ C reservoir ages in Lake Bosten, northwestern China. Front. Earth Sci. 2020, 7, 328. [CrossRef]

56. Liu, W.G.; Liu, Z.H.; An, Z.S.; Wang, X.L.; Chang, H. Wet climate during the Little 'Ice Age' in the arid Tarim Basin, northwestern China. Holocene 2011, 21, 409-416.

57. Putnam, A.E.; Putnam, D.E.; Andreu-Hayles, L.; Cook, E.R.; Palmer, J.G.; Clark, E.H.; Wang, C.Z.; Chen, F.; Denton, G.H.; Boyle, D.P.; et al. Little Ice Age wetting of interior Asian deserts and the rise of the Mongol Empire. Quat. Sci. Rev. 2016, 131, 33-50. [CrossRef]

58. He, Y.X.; Zhao, C.; Wang, Z.; Wang, H.Y.; Song, M.; Liu, W.G.; Liu, Z.H. Late Holocene coupled moisture and temperature changes on the northern Tibetan Plateau. Quat. Sci. Rev. 2013, 80, 47-57. [CrossRef] 
59. Blyakharchuk, T.A.; Wright, H.E.; Borodavko, P.S.; van der Knaap, W.O.; Ammann, B. Late Glacial and Holocene vegetational changes on the Ulagan high-mountain plateau, Altai Mountains, southern Siberia. Palaeogeogr. Palaeoclimatol. Palaeoecol. 2004, 209, 259-279. [CrossRef]

60. Schlütz, F.; Lehmkuhl, F. Climatic change in the Russian Altai, southern Siberia, based on palynological and geomorphological results, with implications for climatic teleconnections and human history since the middle Holocene. Veget. His. Archaeob. 2007, 16, 101-118. [CrossRef]

61. Rudaya, N.; Nazarova, L.; Novenko, E.; Andreev, A.; Kalugin, I.A.; Daryin, A.; Babich, V.; Li, H.; Shilov, P. Quantitative reconstructions of Mid- to Late Holocene climate and vegetation in the North-Eastern Altai mountains recorded in Lake Teletskoye. Glob. Planet. Chang. 2016, 141, 12-24. [CrossRef]

62. Hildebrandt, S.; Müller, S.; Kalugin, I.; Darin, A.; Wagner, M.; Rogozin, D.; Tarasov, P. Tracing the North Atlantic decadal-scale climate variability in a late Holocene pollen record from southern Siberia. Palaeogeogr. Palaeoclimatol. Palaeoecol. 2015, $426,75-84$. [CrossRef]

63. Dirksen, V.G.; van Geel, B. Mid to late Holocene climate change and its influence on cultural development in south central Siberia. In Impact of the Environment on Human Migration in Eurasia; Scott, E.M., Yu, A., Zaitseva, A.G., Eds.; Springer: Dordrecht, The Netherlands, 2004; pp. 291-307.

64. Dirksen, V.; van Geel, B.; Kulkova, M.; Zaitseva, G.; Sementsov, A.A.; Scott, E.M.; Cook, G.T.; Plicht, J.; Lebedeva, L.M.; Bourova, N.D.; et al. Chronology of Holocene Climate and Vegetation Changes and Their Connection to Cultural Dynamics in Southern Siberia. Radiocarbon 2007, 49, 1103-1121. [CrossRef]

65. Blyakharchuk, T.; Prikhodko, V.; Kilunovskaya, M.; Li, H.-C. Vegetation and climate reconstruction based on pollen and microbial records derived from burial mounds soil in Tuva Republic, Central Asia. Quat. Int. 2019, 507, 108-123. [CrossRef]

66. Grunert, J.; Lehmkuhl, F.; Walther, M. Paleoclimatic evolution of the Uvs Nuur basin and adjacent areas (Western Mongolia). Quat. Int. 2000, 65-66, 171-192. [CrossRef]

67. Yang, Y.; Min, R.; Sun, A.Z. Pollen-recorded bioclimatic variations of the last 2000 years retrieved from Bayan Nuur in the western Mongolian Plateau. Boreas 2020, 49, 350-362. [CrossRef]

68. Peck, J.A.; Khosbayar, P.; Fowell, S.J.; Pearce, R.B.; Ariunbileg, S.; Hansen, B.C.S.; Soninkhishig, N. Mid to Late Holocene climate change in north central Mongolia as recorded in the sediments of Lake Telmen. Palaeogeogr. Palaeoclimatol. Palaeoecol. 2002, 183, 135-153. [CrossRef]

69. Tian, F.; Herzschuh, U.; Dallmeyer, A.; Xu, Q.; Mischke, S.; Biskaborn, B.K. Environmental variability in the monsoon-westerlies transition zone during the last 1200 years: Lake sediment analyses from central Mongolia and supra-regional synthesis. Quat. Sci. Rev. 2013, 73, 31-47. [CrossRef]

70. Wang, W.; Ma, Y.; Feng, Z.; Meng, H.; Sang, Y.; Zhai, X. Vegetation and climate changes during the last 8660 cal. a BP in central Mongolia, based on a high-resolution pollen record from Lake Ugii Nuur. Chin. Sci. Bull. 2009, 54, 1579-1589. [CrossRef]

71. Wang, W.; Ma, Y.; Feng, Z.; Narantsetseg, T.; Liu, K.-B.; Zhai, X. A prolonged dry mid-Holocene climate revealed by pollen and diatom records from Lake Ugii Nuur in central Mongolia. Quat. Int. 2011, 229, 74-83. [CrossRef]

72. Ma, J.Z.; Edmunds, W.M. Groundwater and lake evolution in the Badain Jaran desert ecosystem, Inner Mongolia. Hydroge. J. 2006, 14, 1231-1243. [CrossRef]

73. Gates, J.B.; Edmunds, W.M.; Ma, J.Z.; Sheppard, P.R. A 700-year history of groundwater recharge in the drylands of NW China. Holocene 2008, 18, 1045-1054. [CrossRef]

74. Xu, H.; Lan, J.H.; Sheng, E.G.; Liu, B.; Yu, K.K.; Ye, Y.D.; Shi, Z.G.; Cheng, P.; Wang, X.L.; Zhou, X.Y.; et al. Hydroclimatic contrasts over Asian monsoon areas and linkages to tropical Pacific SSTs. Sci. Rep. 2016, 6, 33177. [CrossRef] [PubMed]

75. Vorren, K.-D.; Jensen, C.E.; Nilssen, E. Climate changes during the last c. 7500 years as recorded by the degree of peat humification in the Lofoten region, Norway. Boreas 2012, 41, 13-30. [CrossRef]

76. Kobashi, T.; Goto-Azuma, K.; Box, J.E.; Gao, C.C.; Nakaegawa, T. Causes of Greenland temperature variability over the past 4000 yr: Implications for northern hemispheric temperature changes. Clim. Past. 2013, 9, 2299-2317. [CrossRef]

77. Salzer, M.W.; Bunn, A.G.; Graham, N.E.; Hughes, M.K. Five millennia of paleotemperature from tree-rings in the Great Basin, USA. Clim. Dynam. 2014, 42, 1517-1526. [CrossRef]

78. Holzhauser, H.; Magny, M.; Zumbühl, H.J. Glacier and lake-level variations in west-central Europe over the last 3500 years. Holocene 2005, 15, 789-801. [CrossRef]

79. Moberg, A.; Sonechkin, D.M.; Holmgren, K.; Datsenko, N.M.; Karlen, W. Highly variable Northern Hemisphere temperatures reconstructed from low- and high-resolution proxy data. Nature 2005, 433, 613-617. [CrossRef]

80. Mann, M.E.; Zhang, Z.H.; Hughes, M.K.; Bradley, R.S.; Miller, S.K.; Rutherford, S.; Ni, F.B. Proxy-based reconstructions of hemispheric and global surface temperature variations over the past two millennia. Proc. Natl. Acad Sci. USA 2008, 105, 13252-13257. [CrossRef]

81. Ljungqvist, F.C. A new reconstruction of temperature variability in the extra-Tropical Northern Hemisphere during the last two millennia. Geogr. Ann. Ser. A Phyl. Geog. 2010, 92, 339-351. [CrossRef]

82. Esper, J.; Frank, D.C.; Timonen, M.; Zorita, E.; Wilson, R.J.S.; Luterbacher, J.; Holzkamper, S.; Fischer, N.; Wagner, S.; Nievergelt, D.; et al Orbital forcing of tree-ring data. Nat. Clim. Chang. 2012, 2, 862-866. [CrossRef]

83. Consortium, P.k. Continental-scale temperature variability during the past two millennia. Nat. Geosci. 2013, 6, 339-346. [CrossRef] 
84. Blyakharchuk, T.A.; Chernova, N.A. Vegetation and climate in the Western Sayan Mts according to pollen data from Lugovoe Mire as a background for prehistoric cultural change in southern Middle Siberia. Quat. Sci. Rev. 2013, 75, 22-42. [CrossRef]

85. Ganyushkin, D.; Chistyakov, K.; Volkov, I.; Bantcev, D.; Kunaeva, E.; Brandová, D.; Raab, G.; Christl, M.; Egli, M. Palaeoclimate, glacier and treeline reconstruction based on geomorphic evidences in the Mongun-Taiga massif (south-eastern Russian Altai) during the Late Pleistocene and Holocene. Quat. Int. 2018, 470, 26-37. [CrossRef]

86. Chernykh, D.V.; Galakhov, V.P.; Zolotov, D.V. Synchronous fluctuations of glaciers in the Alps and Altai in the second half of the Holocene. Holocene 2013, 23, 1074-1079. [CrossRef]

87. Chen, J.Y. A Preliminary Study on Holocene Glacial Changes, Lichen Chronology and Other Issues at the Headwaters of Urumqi River, Tianshan Mountains. Sci. China Ser. B 1988, 18, 95-104.

88. Chen, Y.X.; Li, Y.K.; Wang, Y.Y.; Zhang, M.; Cui, Z.J.; Yi, C.L.; Liu, G.N. Late Quaternary glacial history of the Karlik Range, easternmost Tian Shan, derived from ${ }^{10}$ Be surface exposure and optically stimulated luminescence datings. Quat. Sci. Rev. 2015, 115, 17-27. [CrossRef]

89. He, Y.X.; Liu, W.G.; Zhao, C.; Wang, Z.; Wang, H.Y.; Liu, Y.; Qin, X.Y.; Hu, Q.H.; An, Z.S.; Liu, Z.H. Solar influenced late Holocene temperature changes on the northern Tibetan Plateau. Chin. Sci. Bull. 2013, 58, 1053-1059. [CrossRef]

90. Yi, C.; Liu, K.; Cui, Z.; Jiao, K.; Yao, T.; He, Y. AMS radiocarbon dating of late Quaternary glacial landforms, source of the Urumqi River, Tien Shan-a pilot study of ${ }^{14} \mathrm{C}$ dating on inorganic carbon. Quat. Int. 2004, 121, 99-107. [CrossRef]

91. Li, Y.; Liu, G.; Chen, Y.; Li, Y.; Harbor, J.; Stroeven, A.P.; Caffee, M.; Zhang, M.; Li, C.; Cui, Z. Timing and extent of Quaternary glaciations in the Tianger Range, eastern Tian Shan, China, investigated using ${ }^{10}$ Be surface exposure dating. Quat. Sci. Rev. 2014, 98, 7-23. [CrossRef]

92. Ganiushkin, D.; Chistyakov, K.; Kunaeva, E. Fluctuation of glaciers in the southeast Russian Altai and northwest Mongolia Mountains since the Little Ice Age maximum. Environ. Earth Sci. 2015, 74, 1883-1904. [CrossRef]

93. Chen, J.H.; Chen, F.H.; Feng, S.; Huang, W.; Liu, J.B.; Zhou, A.F. Hydroclimatic changes in China and surroundings during the Medieval Climate Anomaly and Little Ice Age: Spatial patterns and possible mechanisms. Quat. Sci. Rev. 2015, 107, 98-111. [CrossRef]

94. Lahijani, H.A.K.; Rahimpour-Bonab, H.; Tavakoli, V.; Hosseindoost, M. Evidence for late Holocene highstands in Central Guilan-East Mazanderan, South Caspian coast, Iran. Quat. Int. 2009, 197, 55-71. [CrossRef]

95. Naderi Beni, A.; Lahijani, H.; Harami, R.M.; Arpe, K.; Leroy, S.A.G.; Marriner, N.; Berberian, M.; Andrieu-Ponel, V.; Djamali, M.; Mahboubi, A.; et al. Caspian sea-level changes during the last millennium: Historical and geological evidence from the south Caspian Sea. Clim. Past. 2013, 9, 1645-1665. [CrossRef]

96. Yao, Y.; Lan, J.H.; Zhao, J.J.; Vachula, R.S.; Xu, H.; Cai, Y.J.; Cheng, H.; Huang, Y.S. Abrupt Freshening Since the Early Little Ice Age in Lake Sayram of Arid Central Asia Inferred From an Alkenone Isomer Proxy. Geophy. Res. Lett. 2020, 47, GL089257. [CrossRef]

97. Rossabi, M. All the Khan's horses. Nat. Hist. 1994, 103, 48-57.

98. Zhang, P.Z.; Cheng, H.; Edwards, R.L.; Chen, F.H.; Wang, Y.J.; Yang, X.L.; Liu, J.; Tan, M.; Wang, X.F.; Liu, J.H.; et al. A test of climate, sun, and culture relationships from an 1810-year Chinese cave record. Science 2008, 322, 940-942. [CrossRef] 